RASĀYAN J. Chem.

Vol. 13 | No. 1 |570 - 573| January - March | 2020 ISSN: 0974-1496 | e-ISSN: 0976-0083 | CODEN: RJCABP

\title{
ANTI-DIABETIC PROPERTY OF GREEN SYNTHESIZED ZINC-OXIDE NANOPARTICLES FROM LEAF EXTRACT OF Chrysanthemum indicum PLANT
}

\author{
Neha Silas ${ }^{1, *}$ and Reena S. Lawrence ${ }^{2}$ \\ ${ }^{1}$ Department of Chemistry/Sam Higginbottom University of Agriculture Technology \& Sciences \\ 211007, (U.P) India \\ ${ }^{2}$ Department of Chemistry/Sam Higginbottom University of Agriculture Technology \&Sciences, \\ 211007, (U.P) India \\ *E-mail: silasneha@gmail.com
}

\begin{abstract}
Diabetes mellitus gives a particular mortality and diabetes belonging tangles. Traditional medicines are applied in control of diabetes mellitus but are expensive and are not easily receivable and as well keep several side effects. Herbal plants used in diabetes mellitus treatment are considered to be inexpensive and easily acquirable. In recent studies nanoparticles of zinc oxide were estimated to check the anti-diabetic property. 36 rats of weight 150-200 gm and age 6-8 weeks were used. The study showed that zinc oxide nanoparticles showed considerably reduced blood glucose in diabetic rats. In inference, the nanoparticles of zinc oxide act as proponents' anti-diabetic agent.

Key-Words: - Diabetic Mellitus, Diabetic Activity, Zinc Oxide Nanoparticles, Anti-diabetic Agent.
\end{abstract}

(C) RASĀYAN. All rights reserved

\section{INTRODUCTION}

Diseases with the clinical features of diabetes have been recognized since antiquity. The Ebers papyrus, dating from $1500 \mathrm{BC}$ depict a polyuric manifest that resembles diabetes. The word 'diabetes' was at first applied by Aretacus of Cappadocia in the second centenary AD. Diabetes is a deficit in the body's capability to modify glucose (sugar) to energy. Glucose is the main resource of energy for our body. When food assimilate it is exchanged in the form of fats, proteins or carbohydrates. Foods that affect blood sugar are called carbohydrates. Carbohydrates when digested change into glucose. Example- bread, pasta, potatoes, corn, fruits and milk products. Particular with transpose to the blood and is employed by cells for energy. In this way for glucose to be transpose from blood into the cells, the hormone-insulin is expected. One of the essential components in our body is Insulin which is a hormone that go through by means of pancreas, the work of pancreas is to promote glucose which enter in the cells and give energy to the body. The prevalence of diabetes mellitus is rising and it is now the seventh salient reason for death in the USA. In the present time, the current rate of diabetics increased (6\% per year), the number of diabetic patients is increasing day by day and it will be double in coming 15years. Epidemiol logically, diabetes mellitus has been connected to the western lifestyle and is unusual in upbringing consuming a more "primitive" diet. All modus of diabetes are on the outclass, type 2 diabetes in exclusive the people who are suffering from diabetes will increase by $55 \%$ by 2035 .

\section{Collection of Samples}

\section{EXPERIMENTAL}

The leaf of Chrysanthemum indicum, gathered from the Department of Horticulture, SHUATS, Prayagraj.

\section{Place of Work}

The present work was carried out in the Department of Pharmacy, United Institute of Pharmacy, UCER, Prayagraj.

Rasayan J. Chem., 13(1), 570-573(2020)

http://dx.doi.org/10.31788/RJC.2020.1315417

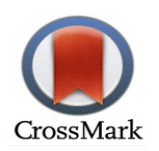


RASĀYAN J. Chem.

Vol. 13 | No. 1 |570 - 573| January - March | 2020

Drug, Chemicals and Instruments

Streptozotocin (STZ) chemical name 2 deosil-2-(3-methyl-3-nitroso urea), citrate buffer, metformin, zinc oxide nanoparticles. Test-tubes, Capillary Tubes, Blood Glucose Monitoring System.

\section{Preparation of Zinc Oxide Nanoparticles}

The zinc oxide nanoparticles synthesized using the Chrysanthemum indicum plant extract. $1 \mathrm{ml}$ of Chrysanthemum indicum extract will be taken and boiled to $60-80^{\circ} \mathrm{C}$ using a stirrer-heater. $1 \mathrm{mM}$ Zinc Nitrate solution $(9 \mathrm{ml})$ is added to the solution as the temperature reaches $60^{\circ} \mathrm{C}$, the mixture is then boiled till it turn into a pale- yellow coloured solution. This indicates the formation of $\mathrm{ZnO}$ nanoparticles.

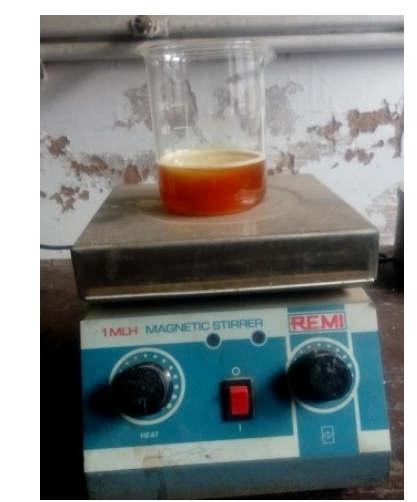

Fig.-1: C.indicum Leaf Extract

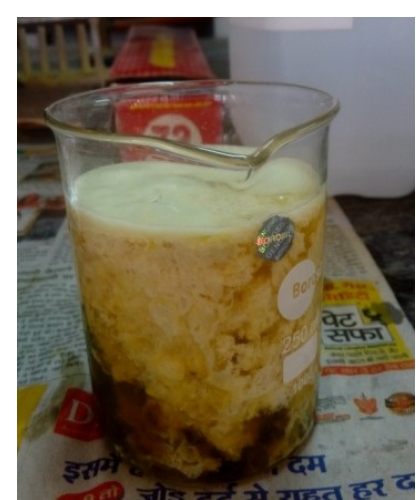

Fig.-2: Formation of $\mathrm{ZnO} \mathrm{NPs}$

\section{Animals involved in the Study}

Young male Wister rats which were 7-8 weeks old weighing 150-200 gm was taken from inbred animal house of C.D.R.I, Lucknow. The animals were kept in polypropylene cages in the favorable environmental conditions of $12 \mathrm{~h}$ light and $12 \mathrm{~h}$ dark at room temperature. The rats were given with the standard laboratory pellet diet and water. At least 15 days before the experiment, rats were made habitual to the laboratory condition and prepare for the experiment. To maintain the laboratory condition, they were kept in a well ventilated animal house. The experimental protocol was approved by the Institutional Animal Ethical Committee (IAEC) animal and the care of the laboratory was taken as per the CPCSEA regulation (Reg. No1451/PO/Re/S/11/CPCSEA Dated 06/05/2018).

\section{Determination of Oral Acute Toxicity Study}

As per the Organization for Economic Co-operation and Development (OECD), Guideline 423 A, the lethal medium dose (LD- 50) was performed in rats to start the experiment.

\section{Preparation of Extract Dose}

Weighed quantity of zinc oxide nanoparticles was suspended in water and delivered orally to experimental animals. Suspension of extract was prepared freshly. The extract was administered at a dose of $200-400 \mathrm{mg} / \mathrm{kg}$ of body weight.

\section{EXPERIMENTAL}

The solution of STZ (50 mg/kg of body weight) in $0.1 \mathrm{M}$ citrate buffer was freshly injected intraperitoneally in a volume of $1 \mathrm{ml} / \mathrm{kg}$. After injecting STZ to the animals they show hyperglycemia within 2 days. By measuring the fasting blood glucose level after 48 hours after the injection of STZ, diabetes was confirmed. In STZ rats, the rats whose blood glucose level over $200 \mathrm{mg} / \mathrm{dl}$ was indicated as diabetic and grouped in different groups for further experiments.

\section{Research Design and Procedure}

Five groups of rats were used to study the effect of Chrysanthemum indium nanoparticles. Each group having six rats.

Group I: The control rats, administered interaperitoneally or orally with normal saline solution. 
RASĀYAN J. Chem.

Vol. 13 | No. 1 |570 - 573| January - March | 2020

Group II: Diabetic control rats, administered interaperitoneally or orally with normal saline solution.

Group III: Diabetic rats, administered interaperitoneally or orally with extract $200 \mathrm{mg} / \mathrm{kg}$ body weight.

Group IV: Diabetic rats, administered interaperitoneally or orally with extract at $400 \mathrm{mg} / \mathrm{kg}$ body weight. Group V: Diabetic rats, administered interaperitoneally or orally with leaf extract of Chrysanthemum Indicum.

Group VI: Diabetic rats, administered interaperitoneally or orally with the standard drug metformin at $100 \mathrm{mg} / \mathrm{kg}$ body weight.

\section{Anti-hyperglycemic Activity}

All the rats were kept inside the cage for 3 days to adapt to the experimental condition, after which they have fasted overnight. Diabetes was determined in rats by intraperitoneal injection of STZ dose of 50 $\mathrm{mg} / \mathrm{kg}$ which was dissolved in normal saline. All the animals were given food and water after the STZ treatment. 2 days after STZ injection, blood glucose level was checked and used as parameter to match pair of diabetic rats with an identical level of intensity only the rats whose fasting blood glucose level is higher than $200 \mathrm{mg} / \mathrm{dl}$ were consider to be diabetic and used in experiment. In normal rats, the mean blood concentration of glucose was $86 \mathrm{mg} / \mathrm{dl}$. Animals were separated into 6 different groups of 6 rats i.e I to VI. Normal control rats were named as Group I. two days after STZ injection, the treatment was started. By using oral gavages tube, the drugs were administered daily, orally for 3 weeks. Blood samples were collected from eyesight for the measurement of blood glucose levels. The blood glucose level was checked by glucometer (one-touch).

\section{RESULTS AND DISCUSSION}

The effect of oral administration of zinc oxide nanoparticles of Chrysanthemum Indicum on blood glucose level of animals in 21 days is depicted in Table-1.

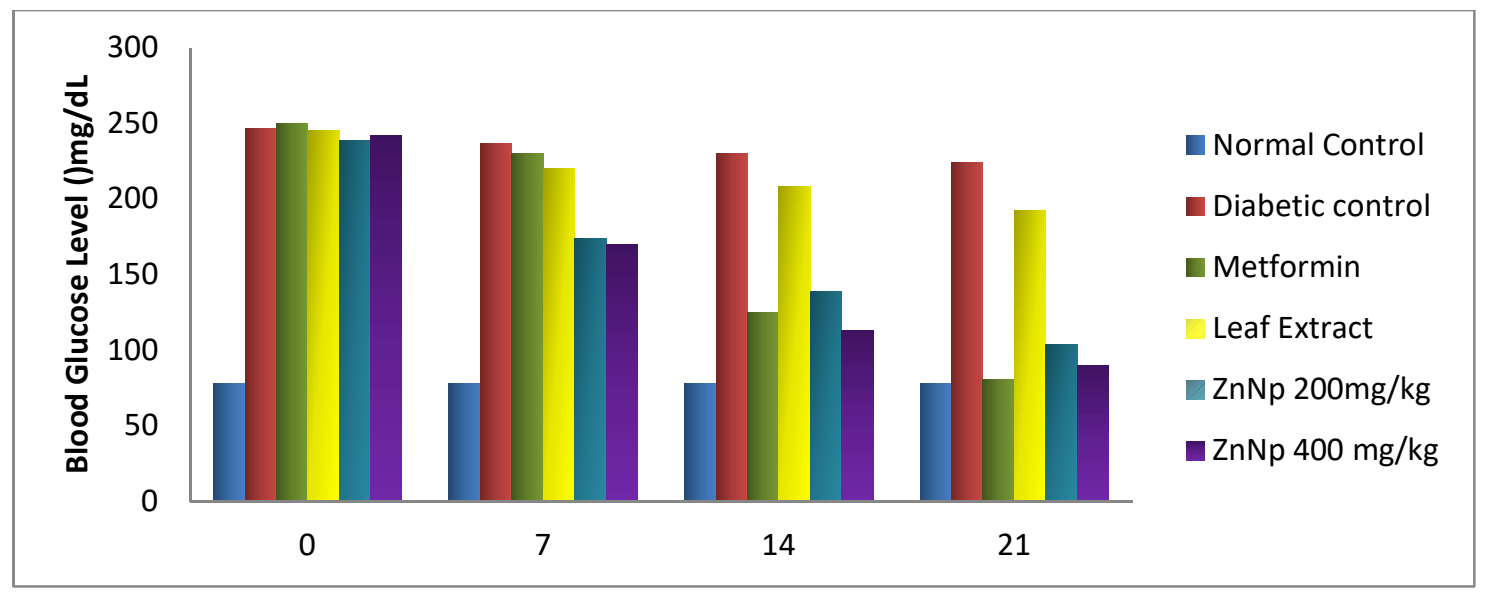

Fig.-3: Graph Showing Blood Glucose Levels in STZ-induced Diabetic Rats in 21 days

\begin{tabular}{c|c|c|c|c}
\multicolumn{7}{c}{ Table-1 } \\
\hline $\begin{array}{c}\text { Treatment } \\
(\text { Dose })\end{array}$ & $\begin{array}{c}\text { 0 Day } \\
(\mathrm{mg} / \mathrm{dL})\end{array}$ & $\begin{array}{c}7^{\text {th }} \text { Day } \\
(\mathrm{mg} / \mathrm{dL})\end{array}$ & $\begin{array}{c}14^{\text {th }} \text { Day } \\
(\mathrm{mg} / \mathrm{dL})\end{array}$ & $\begin{array}{c}21^{\text {st }} \text { Day } \\
(\mathrm{mg} / \mathrm{dL})\end{array}$ \\
\hline Normal Control & $78.12 \pm 6,51$ & $78.81 \pm 4.91$ & $78.0 \pm 5.72$ & $78.0 \pm 2.49$ \\
\hline Diabetic Control & $247.83 \pm 18.81$ & $237.16 \pm 17.12$ & $230.33 \pm 16.41$ & $224.50 \pm 14.54^{\mathrm{z}}$ \\
\hline Metformin $(100 \mathrm{mg} / \mathrm{kg})$ & $250.14 \pm 13.02$ & $180.50 \pm 10.59^{* * *}$ & $125.55 \pm 15.33^{* * * *}$ & $81.16 \pm 15.92^{* * *}$ \\
\hline Leaf Extract $(200 \mathrm{mg} / \mathrm{kg})$ & $245.40 \pm 11.71$ & $220.14 \pm 14.12$ & $208.22 \pm 12.07$ & $192.44 \pm 10.32$ \\
\hline ZnNp $(200 \mathrm{mg} / \mathrm{kg})$ & $239.40 \pm 11.71$ & $174.40 \pm 7.79^{* * *}$ & $139.22 \pm 10.01^{* * *}$ & $104.83 \pm 9.39^{* * *}$ \\
\hline Zn Np $(400 \mathrm{mg} / \mathrm{kg})$ & $242.55 \pm 12.65$ & $170.40 \pm 11.11^{* * *}$ & $113.55 \pm 11.13^{* * *}$ & $90.00 \pm 6.92^{* * *}$ \\
\hline
\end{tabular}

The data represents the mean \pm SD for six rats per group $\mathrm{p}<0.001$ as compared to normal controls. ${ }^{* * *} \mathrm{p}<0.001$ as compared to diabetic control.

\section{CONCLUSION}

The objective of this research work was to evaluate the zinc oxide nanoparticles prepared from Chrysanthemum indicum for anti-hyperglycemic activity. Diabetes mellitus is the most common 
RASĀYAN J. Chem.

Vol. 13 | No. 1 |570 - 573| January - March | 2020

endocrine disorder which is characterized by hyperglycemia, altered metabolism of protein, lipid and carbohydrates. By the suppression of glucose output from the liver, it is possible to maintain the blood glucose level. Based on our present experiment it can be suggested that Zinc oxide nanoparticles of Chrysanthemum indicum may prevent hyperglycemia in STZ induced rats. The result suggests that nanoparticles treatment posses as anti-diabetic activity in STZ induced diabetic rats.

\section{ACKNOWLEDGMENT}

The author is thankful to the Head of Department of Pharmacy, United Institute of Pharmacy, UCER, Prayagraj, their staff for providing the Lab Facilities and Guidance and Advisor for the Moral Support.

1. S. Lenzen, Diabetologia, 51(22), 216(2008)

\section{REFERENCES}

2. D. Edem, , I. Ekanem and P. Ebong, Pakistan Journal of Pharmaceutical Sciences, 22(3), 272(2009)

3. CDC, 2015 Basic about Diabetes, Available at http;//www.cdc.gov/diabetes/basic

4. P.M. Thule, A.G. Campbell, D. Jia, Y. Lin, S. You, S. Paveglio, D.E. Olson and M. Kozlowski, The Journal of Gene Medicine, 17 (8-9), 141(2015), DOI:10.1002/lgm.2835

5. E. Ferrannini. The New England Journal of Medicine, 371(16), 1547(2014), DOI:10.1056/NEJMcibr1409796

6. X.F. Zhang and B.K. H. Tan, Singapore Medical Journal, 41(1), 9(2000)

7. M. Brownlee. Nature, 414 (6865), 813(2001)

8. H. Haase, S. Overbeck and L. Rink, Experimental Gerontology, 43(5), 394(2007), DOI: 10.1016/J.exger.2007.12.002

9. R. D. Umrani and, K. M. Paknikar, Nanomedicine(Lond), 9(1), 89(2014), DOI:10.2217Mnm.12.205

10. T.C. Yih and M. Al-Fandi, Journal of Cellular Biochemistry, 97(6), 1184(2006)

11. V. Vadlapudi, M. Behare and M.N. Devamma, Rasayan Journal of Chemistry, 7, 219(2014)

12. H. Meruvu, M. Vangalpati, S. C. Chippada and S.R. Bammidi, Rasayan Journal of Chemistry, 4 217(2011)

13. G. M. Srirangam and K.P. Rao, Rasayan Journal of Chemistry, 10, 46(2017)

14. C. V. Abiaziem, A. B. Williams, A. I. Inegbenebor, C. T. Onwordi, C. O. Ehi-Eromosele and L. F. Petrik, Rasayan Journal of Chemistry, 13(1), 177(2020), DOI:10.31788/RJC.202.1315328

[RJC-5417/2019] 